\title{
Effect of using Stone Cutting Waste as Additive to Concrete Mix
}

\author{
${ }^{1}$ Mohammad Al-Rawashdeh, ${ }^{2}$ Ashraf Adel Shaqadan, ${ }^{1}$ Jamal Al-Adwan and ${ }^{1}$ Ahmed Essa Alzoubi \\ ${ }^{1}$ Department of Civil Engineering, Al-Balqa Applied University, P.O. Box: 19 117, Salt, Jordan \\ ${ }^{2}$ Civil Engineering Department, Zarqa University, P.O. Box: 132222, Zarqa, Jordan
}

(+962-5) 3491111, Fax: (+962-5) 3491111

\begin{abstract}
Stone cutting industry produces slurry waste that causes environmental pollution problems and its dis posal is controlled. In addition stone cutting slurry can improve concrete mix properties such compressive andtensilestrength when add at proper amounts. In this research, we investigate the impact of adding different fractions of cutting slurry waste on important concrete properties. To analyze slurry impact several levels are added and tested. Concrete and mortar samples were prepared with $25,50,75$ and $100 \%$ of water esults shamount. Standard laboratory methods are used to analyze compressive, flexural and tensile strength. Row that adding slurry waste has improved slump test performance and to improved compressive, tensile and flexural strength up to $50 \%$ of slurry addition. A robust trend of increasing workability is observed with increasing slurry fraction.
\end{abstract}

Key words: Stone cutting waste, slurry water, concrete, compressive, tensile, flexural, workability

\section{INTRODUCTION}

Concrete is a basic building material worldwide, the most common ingredients are gravel, sand, Portland cement and water. Concrete is used more than any other mantmade material on the planet. As of 2005 over six billion tons of concrete are made each year (Kosmatka et al., 2002; Topcu and Canbaz, 2007; Altboon and Mahasneh, 2009; Neville and Brooks, 2010).

Concrete main disadvantage is its low tensile stress. Researchers investigated a range of admixtures to improve concrete physical properties (Gambhir, 1986; Raphael, 1984; Tattersall, 1991). In general using admixtures in concrete improves its workability, controlling development of concrete strength and enhancing durability to deterioration process (Persson, 1996; Hamza et al., 2011). Several researchers investigated a range of locally available admixtures in Jordan. Al-Rawashdeh and Shaqadan (2015) investigated the effect of adding basalt aggregate at several fractions of aggregates in concrete mix and analyzed impacts on concrete mix strength and other physical properties (Al-Rawashdeh and Shaqadan (2015). Also, researchers focused on prediction of concrete physical properties with local additives like basalt aggregates using artificial intelligence models (Shaqadan, 2016; Shaqadan and Al-Rawashdeh, 2018).

Research papers that investigated stone cutting slurry as additive to concrete are limited. The environmental pollution that results from cutting stone factories is well known and its disposal is regulated in many countries (Tripathy and Barai, 2006). Every year tons of cutting stone wastes is discarded in landfills which may cause groundwater and soil pollution.

Al-Zboon and Al-Zou'by (2015) investigated adding stone cutting slurry to concrete mix and replaced fraction of water. Researcher investigated some physical properties like compressive and flexural strength for concrete and mortar.

In s tone cutting industry, rock blocks are cut and shaped into different sizes. The cutting is accomplished using metal saws cooled by large amount of water. Water is added on blades during the cutting process to cool blades and absorb dust. Stone cutting plants produce and store large amounts of this wastewater.

Adding stone cutting can enhance the mechanical behavior of concrete mix in engineering properties such as compressive strength and durability and reduce the consumption of raw materials (cement and tap water) and reduce pollution of the environment.

The generated slurry from cutting stones factories is held in separate basins to evaporate significant water amount which produces dense slurry. The suspended partic les settle in local storage basins which increases slurry density.

The stone cutting slurry is considered as pollutant that brings economical and environmental problems such as safe waste storage, transportation and disposal

Corresponding Author: Mohammad Al-Rawashdeh, Department of Civil Engineering, Al-Balqa Applied University, P.O. Box: 19 117, Salt, Jordan, (+962-5) 3491111, Fax: (+962-5) 3491111 


\section{J. Eng. Applied Sci., 14 (19): 7040-7047, 2019}

locations. Stone cutting sludge disposal is regulated and cause significant environmental impacts that motivated research efforts. The fine particles can cause more pollution if not stored properly, especially when storage lagoons are become dry. Fine particles can be easily dispersed after drying, under windy atmospheric conditions (Al-Joulani and Salah, 2014).

The white dust particles are composed of $\mathrm{CaCO}_{3}$ which cause visual pollution. Also, its absorption in soil is limited, soils are efficient for removal of charged particles like metals and captions. Stone dust mainly $\mathrm{CaCO}_{3}$ is uncharged (inert), therefore its absorption is minimal. The particle size of the slurry is $<80 \mu \mathrm{m}$ (Alzboon and Mahasneh, 2009).

The challenge in this research is to reduce the industrial wastes and improve concrete properties. The man objective of this research is to investigate the effect of adding cutting stone slurry at different fractions to concrete on its mechanical properties. The effect of this s lurry on the mechanical properties of concrete under different experimental conditions including slurry content will be determined.

Literature review: In the last decades, many experiments and researches have been done to investigate the influence of different wastes on concrete properties when added at different fractions.

Topcu and Canbaz (2007) investigated adding tile waste in concrete mix. Researcher replaced 0.5 and $100 \%$ ratios of coarse aggregates by tile waste and analyzed physical properties. The test results show that the unit weight of waste tile has decrease $4 \%$, compressive and splitting tensile strength reduction by $40 \%$ and reduced abrasion and freeze-thaw durability.

Senthamarai and Manoharan (2005) studied the performance of concrete with ceramic waste as coarse aggregate. Six ceramic waste coarse aggregate concrete mixes were designed with several water cement ratios. Researcher designed six concrete mixes were with crushed stone course aggregate for comparison. Authors analyzed samples for compressive strength, flexural and splitting tensile strength and modulus of elasticity after 28 days. Tile waste was added with a fraction of $35 \%$ weight ratio and the replacement by waste tile reduced the cost.

Binici et al. (2008) designed concrete mix with crushed limestone and waste marble as coarse aggregate and with granite, river sand and furnace slag as fine aggregate. Researcher analyzed samples compressive strength, splitting tensile strength, flexural strength, young modulus of elasticity, resistance to abrasion, chloride penetration and sulphate resistance were als o determined. The test result indicated that in order to obtain similar slump values, samples made with granite and furnace slag required more super plasticizer than samples that was made with granite and river sand. A decrease in both the air content and slump value of the concrete was observed for the entire sample that includes GBFS. Compressive strength and abrasion resistance of the concrete were strongly influenced by its marble, granite and GBFS content. The addition of marble and granite into concrete reduce the chloride penetration depth about $70 \%$. In the sample containing marble and GBFS there is a much better bonding among the additives.

Almeida et al. (2007) investigated the impact of using large amounts of stone slurry and presented data showing the feasibility of using it for high-performance concrete production as a substitute of fine aggregate. Eight concrete mixtures with stone dust were produced. Replacing $0-100 \%$ of fine aggregate on volume basis. Results show that the properties of fresh high-performance concrete is improved with maximum at $16 \%$. Results show that this mixture is suitable for architectural uses namely related to non protected white concrete.

Silvaet al. (2009) studied the possibility of improving mortar properties through the addition of very fine aggregate from crushed red clay ceramics. Researcher focused on analysis of cementation mortars at several levels. Properties studied are strength, water absorption, shrinkage and water permeability.

Safiuddin et al. (2007) investigated the effect of quarry waste aggregate on fresh and hardened samples of concrete. Four different types of concrete mixture were prepared where quarry waste fine aggregate was used in all concrete samples as a fraction of sand.

Researcher found that quarry waste fine aggregate enhanced slump flow of the fresh concrete. While in hardened concretes, the 28 and 56 days compressive strength of the concretes varied from $40-47 \mathrm{MPa}$.

Tripathy and Barai (2006) analyzed hardened compressive strength of mortar under hot water curing and autoclaving curing condition for cement replacement using crusher stone dust. Mix prepared by replacing applied to the high strength concrete or the super high strength concrete in which the water-cement ratio is $20-35 \%$.

The reuse of slurry from stone cutting industry as mixing water for concrete mixing is the main goal of this 
project. The physical and chemical properties of the slurry will be determined. Various tests such as slump test and strength test will be performed on the concrete where slurry is used. This study is also, planned to minimize cement content in concrete mixes. The produced slurry water in Jordan has shown available suspended solids about 5\% (mainly $\mathrm{CaCO}_{3}$ ). This material is considered as fines constituent of the concrete mix. Alzboon and Mahasneh (2009) analyzed stone cutting slurry composition and tested several fractions and sugges $\mathrm{t}$ $25 \%$ fraction of water added to concrete mix.

High fraction of fine aggregates in the mix improves wokkability but reduces concrete durability. Finer particles require more water to wet their larger specific surface. The absorption of the aggregate means that mixing water will be usedfor lubrication of the particles. The excess of very fine sand particles reduced the amount of entrained air but the material in the 300-600 micrometer range increases it. A more workable mix holds more air. For small particles $(<150 \mu \mathrm{m})$ they appear to act as a lubricant and do not requirewetting in the same way as coarser particles. Fines can also be considered as filler.

Concrete properties overview: Strength and durability generally concrete mix is designed to deliver specified strength. The most common measure of concrete strength is the compressive strength, determined by cube and cylinder tests.

Compressive test: Concrete samples are tested using the ASTM39 Standard Method for Compressive Strength of Cylindrical samples using two cylinders made from the same batch at 28 days old. The test is used to estimate specified strength $\mathrm{f}^{\prime} \mathrm{c}$ to design structural elements. The specified strength is needed for documentation. The concrete mix is designed to produce an average strength ( $f^{\prime}$ c $)$ higher than the specified strength, to reduce the risk of not complying with the specified strength.

Used cylindrical samples are $150 \times 300 \mathrm{~mm}$ size. Concrete mix strength is calculated by dividing maximum load at failure by sample average cross sectional area. Typical concrete compressive strength requirements range from $17 \mathrm{MPa}$ for residential concrete to $30 \mathrm{MPa}$ and higher for commercial buildings. Higher strengths up to $70 \mathrm{MPa}$ are needed for some uses. Cylinders are subjected to compressive pressure until failure from 20-50 psi.

Flexural strength of concrete: The flexural strength represents the highest stress experienced within the material at its moment of rupture. Flexural strength is a physical parameter for brittle material, it is defined as the

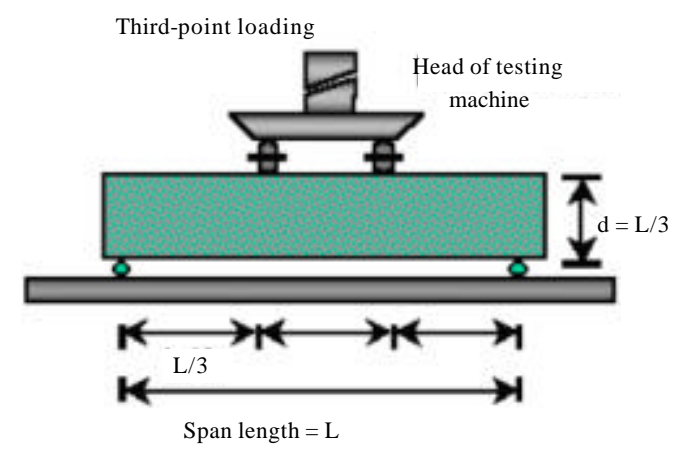

Fig. 1: Schematic of third-point loading flexural strength test

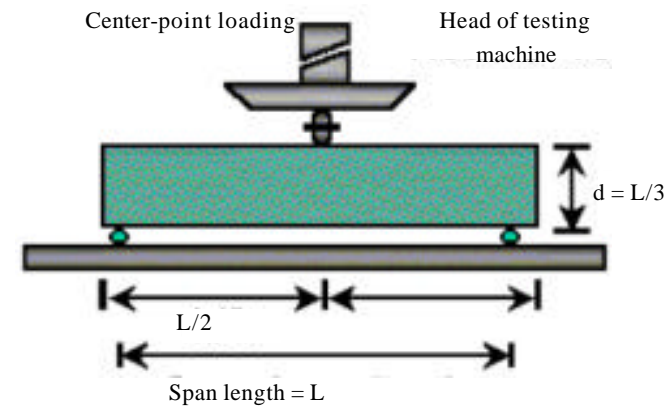

Fig. 2: Center-point loading flexural strength test

sample capacity to resist deformation under load. The transverse bending test uses rod samples having circular/ rectangular cross-section that is bent until sample is fractured using three point flexural test.

The concrete strength used in designing concrete pavement is based on AASHTO Test Method T-97 or ASTM C78 using a simple beam with third-point bading as shown in Fig. 1. The flexural test is conducted using concrete beams that have been cured in the field.

For AASHTO thickness design, the third point loading 28-day flexural strength is used in the AASHTO equation. If the strength values are measured using other methods, it must be converted to the 28-day third-point strength.

Center-point loading forces the beam to fail directly under loading center (Fig. 2). The middle one-third of the testedbeam is uniformly stressed and as a result the beam fails at its weakest point in the middle one-third of the beam. By forcing the beam to fail at the center, the center-point flexural test results are somewhat higher than the third-point test results. These tests provide a reasonable estimate of the concrete's average strength (Raphael 1984; Popovics, 1998; Grieb and Werner, 1962). 
Splitting tensile tests ASTM C496/C496M: This method determines the splitting strength of cylindrical concrete samples, such as molded cylinder and drilled cores. Typically, splitting tensile strength is greater than direct tensile strength and less than flexural strength. Splitting tensile strength is used in designing lightweight concrete to evaluate the shear resistance provided by concrete.

This method is based on applying a diametric compressive force gradually along the length of cylinder s amples within a given range until failure. This loading causes tensile stress on the plane containing the applied load and causes high compressive stresses in the area around the applied load. Tensile failure occurs more likely than compressive failure because the areas of load application are subject to triaxial compression which allows sample to withstand higher compressive strength. Thin, plywood bearing strips are used to apply stres s uniformly along the length axis of cylindrical sample. The maximum load sustained by the sample is divided by geometrical factors in order to obtain the splitting tensile strength (Fig. 3).



Fig. 3: Diagram of splitting tensile test

\section{MATERIALS AND METHODS}

\section{Laboratory testing preparation}

Materials properties: The physical properties of aggregates used in the concrete mix are analyzed and summarized in the following tables. Coarse aggregates properties are shown in Table 1.

Fineaggregates properties are shown in Table 2 . The sand sieve analysis is given in Table 2 . The sample weight use in $1000 \mathrm{gm}$.

Portland cement chemical and physical properties are shown in Table 3. Laboratory testing was done in AlManaser laboratories. Medium aggregates sieving analysis are shown in Table 4. Coarse aggregates sieving analysi are shown in Table 5 . Density and other physical properties are summarized in Table 6. Used cement physical properties are shown in Table 7.

Stone cutting slurry properties: Physical and chemical properties of the stone cutting slurry are determined in orderto investigate the effect of using this slurry as a raw material on the concrete properties. Tests were performed onthe slurry and results are shown in Table 8 . The slurry properties were analyzed using standard methods in A1-Hus on College laboratories of Al-Balqa University. The properties considered are Total Suspended Solids (TSS), Total Dissolved Solids (TDS) and Total Solids (TS). X-ray diffraction method is used to determine chemical components of the slurry. Also, water content and dry sieve of analysis of the slurry are undergoing.

Concrete mix design: The concrete mixture consisted of aggregate, sand with fineness modulus of 2.6, Portland cement, desert silica, slurry water 5,10 and $20 \mathrm{~mm}$

Table 1: Properties of coarse aggregates used in the study

\begin{tabular}{|c|c|c|c|c|c|}
\hline \multirow[b]{2}{*}{ No./Course } & \multirow[b]{2}{*}{ Properties fine } & \multirow[b]{2}{*}{ Units } & \multirow[b]{2}{*}{ Test standard } & \multicolumn{2}{|l|}{ Limits } \\
\hline & & & & Course & Fine \\
\hline$\overline{1}$ & Abrasion & $\%$ & ASTMC131 & 28.5 & \\
\hline 2 & Rodded density & -- & BS812:Part1 & 1430 & 1370 \\
\hline 3 & Loose density & $\%$ & BS812:Part1 & 1325 & 1360 \\
\hline 2.53 & 2.545 & ASTM & -- & Specific gravity & 4 \\
\hline 2.583 & 2.569 & $\mathrm{C} 127$ & -- & Bulk Gs & \\
\hline 2.672 & 2.682 & & $\begin{array}{l}-- \\
\text { Apparent Gs }\end{array}$ & SSD Gs & \\
\hline 5 & Absorption & $\%$ & ASTM C 127 & 2.0 & 2.1 \\
\hline 6 & Clay lumps & $\%$ & ASTM C 142 & 0.72 & 0.88 \\
\hline Coal and liginite and shale & $\% \quad$ ASTM C 123 & 0.23 & 0.30 & 7 & \\
\hline BS 812: Part 118 & 0.22 & 0.18 & Acid soluble/Sulphate content & $\%$ & 8 \\
\hline BS 812: Part 117 & Ni1 Ni1 & \multicolumn{2}{|c|}{ Total acid soluble chloride salts } & $\%$ & 9 \\
\hline 10 & Organic Impurities & -- & ASTM C 42 & Lighter & Lighter \\
\hline Soundness (sodium sulphate) & $\%$ & ASTM C 88 & 8.7 & 9.3 & 11 \\
\hline 12 & Flakiness index & $\%$ & BS 812:Part $105 \mathrm{sec} 105.1$ & 18.5 & 19.2 \\
\hline 13 & Elongation index & $\%$ & BS 812:Part $105 \mathrm{sec} 105.2$ & 21.4 & 19.5 \\
\hline
\end{tabular}


Table 2: Sieve analysis for silica used in the study

\begin{tabular}{lc}
\hline Sieve opening $(\mu \mathrm{m})$ & Remaining on sieve $(\mathrm{gm})$ \\
\hline 2800 & 15.66 \\
2000 & 6.30 \\
850 & 19.84 \\
355 & 271.56 \\
150 & 632.28 \\
Remaining on tray & 59.50 \\
\hline & \\
Table 3: Sieve analysis for fine aggregates & \\
\hline Sieve opening $(\mu \mathrm{m})$ & Remaining on sieve $(\mathrm{gm})$ \\
\hline 4000 & 232.44 \\
2800 & 117.43 \\
2000 & 126.45 \\
850 & 181.57 \\
355 & 139.17 \\
150 & 145.36 \\
Remaining on tray & 57 \\
\hline
\end{tabular}

Table 4: Sieve analysis for medium aggregates

\begin{tabular}{lc}
\hline Sieve opening $(\mu \mathrm{m})$ & Remaining on sieve $(\mathrm{gm})$ \\
\hline 13,200 & 207.63 \\
8000 & 695.43 \\
5600 & 93.86 \\
4000 & --- \\
Remaining on tray & --- \\
\hline
\end{tabular}

limestone and potable water were use in this study. These following proportions (Table 9) were tested, according to the Jordanian code and recommended as successful mix design that yields $15 \mathrm{MPa}$ compressive strength and 150 mmslump. Mortar samples mix constituents are shown in Table 10.

The slurry was mixed with tap water at several proportions as shown in Table 11. The mix of tap water andslurry was added gradually to the dry components of the mix.

Laboratory testing methods: In this study, several types of samples are prepared including cubes and cylinders, and several laboratory tests are conducted as shown in Table 12.

Table 5: Sieve analysis for coarse gravel agoregates

\begin{tabular}{lc}
\hline Sieve opening $(\mu \mathrm{m})$ & Remaining on sieve $(\mathrm{gm})$ \\
\hline 19,000 & 181 \\
13,200 & 745.6 \\
8000 & 67.20 \\
5600 & --- \\
Remaining on tray & --- \\
\hline
\end{tabular}

Table 6: Fine aggregates physical properties

\begin{tabular}{|c|c|c|c|c|c|}
\hline \multirow[b]{2}{*}{ No. } & \multirow[b]{2}{*}{ Properties fine } & \multirow[b]{2}{*}{ Units } & \multirow[b]{2}{*}{ Test standard } & \multicolumn{2}{|l|}{ Fine aggregate } \\
\hline & & & & Crushed semsemeyah & Silica sand \\
\hline 1 & Rodded density & -- & BS 812: Part 1 & 1490 & 1680 \\
\hline 2 & Loose density & $\%$ & BS 812: Part 1 & 1450 & 1580 \\
\hline 2.571 & 2.469 & ASTM & -- & Specific gravity & 3 \\
\hline 2.597 & 2.546 & C128 & -- & Bulk Gs & \\
\hline 2.639 & 2.674 & & -- & SSD Gs/apparent Gs & \\
\hline 4 & Absorption & $\%$ & ASTM C 128 & 3.1 & 1.0 \\
\hline 5 & Clay lumps & $\%$ & ASTM C 142 & 0.58 & Nil \\
\hline 6 & Coal and lignite & $\%$ & ASTM C 123 & 0.18 & 0.2 \\
\hline BS 812: Part 118 & 0.12 & 0.188 & Acid soluble/sulphate content & $\%$ & 7 \\
\hline 8 & Chloride content & $\%$ & BS 812:Part117 & 0.024 & Ni1 \\
\hline Organic impurities & ASTM C 42 & Lighter & Lighter & 9 & \\
\hline Soundness (sodiu m sulphate) & $\%$ & ASTM C 88 & 3.76 & 5.32 & 10 \\
\hline 11 & Sand equivalent & $\%$ & ASTM D2 419 & - & - \\
\hline
\end{tabular}

Table 7: Physical Properties of Portland cement used in the study

\begin{tabular}{lc}
\hline Property & Values \\
\hline Specific gravity & 3.15 \\
Blaine fineness $\left(\mathrm{m}^{2} / \mathrm{kg}\right)$ & 330 \\
Average particle $s i z e(\mu \mathrm{m})$ & 13 \\
Color & grey \\
\hline
\end{tabular}

Table 8: Chemical and physical properties of stone cutting slurry

\begin{tabular}{ll}
\hline Parameters & Units \\
TS (slurry) & $50000(\mathrm{mg} / \mathrm{L})$ \\
$\mathrm{COD}$ & $0.0(\mathrm{mg} / \mathrm{L})$ \\
Total hardness & $560(\mathrm{mg} / \mathrm{L})$ \\
$\mathrm{SO} 2-$ & $120(\mathrm{mg} / \mathrm{L})$ \\
$\mathrm{Alkalinity}$ & $640(\mathrm{mg} / \mathrm{L})$ \\
$\mathrm{PH}$ (slurry) & 8.4 \\
$\mathrm{SiO}_{2}$ & $0.83(\mathrm{wt} . \%)$ \\
$\mathrm{Al}_{2} \mathrm{O}_{3}$ & $0.21(\mathrm{wt} . \%)$ \\
$\mathrm{Fe}_{2} \mathrm{O}_{3}$ & $0.11(\mathrm{wt} . \%)$ \\
$\mathrm{MgO}$ & $910(\mathrm{wt} . \%)$ \\
$\mathrm{CaO}$ & $54.22(\mathrm{wt} . \%)$ \\
\hline
\end{tabular}


Table 8: Continue

\begin{tabular}{ll}
\hline Parameters & Units \\
\hline $\mathrm{Cl}$ & $0($ wt.\%) \\
$\mathrm{K}_{2} \mathrm{O}$ & 0 (wt.\%) \\
$\mathrm{SO}_{3}$ & $0.11($ wt.\%) \\
$\mathrm{LSF}$ & 2064.34 \\
$\mathrm{SR}$ & 2.53 \\
$\mathrm{AR}$ & 1.88 \\
$\mathrm{LOI}$ & $43.6(\%)$ \\
\hline
\end{tabular}

Table 9: Concrete mix design proportions

\begin{tabular}{|c|c|c|c|c|c|c|c|}
\hline Component & $\begin{array}{l}\text { Coarse } \\
\text { gravel }\end{array}$ & Medium & Fine & Silica & Cement & $\begin{array}{l}\text { Slurry+ } \\
\text { water }\end{array}$ & Total \\
\hline Weight (kg) & 13.50 & 16.35 & 10.80 & 16.50 & 9.00 & 7.250 & 73.4 \\
\hline
\end{tabular}

Table 10: Mix design proportions for mortar

\begin{tabular}{llll}
\hline Component & Silica & Cement & Water \\
\hline Weight $(\mathrm{g})$ & 3000 & 1000 & 700 \\
\hline
\end{tabular}

Table 11: Proportion of tap water to slurry water

\begin{tabular}{lcc}
\hline Sample & Tap water $(\%)$ & Shry water $(\%)$ \\
\hline 1 & 100.0 & 0.0 \\
2 & 75.0 & 25.0 \\
3 & 50.0 & 50.0 \\
4 & 25.0 & 75.0 \\
5 & 0.0 & 100.0 \\
\hline
\end{tabular}

Table 12: Summary of laboratory testing methods used

Test

Concrete mix

Slump test

Compressive strength

Splitting tensile strength

Flexural strength

Mortar

Flexural strength

$\underline{\text { Bar test }}$

Method
ASTM C143
BS 12390-3:2002:
ASTM C 496
ASTM C 293
ASTM C 293
ASTM C227-97a

\section{RESULTS AND DISCUSSION}

The results for compression are shown in Fig. 4 for 28 -day test. The results indicate that cure concrete samples with $50 \%$ slurry water gives the best compressive were $20 \%$ increased, according to standard values which only consist of tap water. That's mean slurry water give highperformance when use it in concrete mixes more than use tap water only.

The average and range of strength data are plotted as a function of slurry fraction to identify robustness of trend as shown in Fig. 5. The 50 and $75 \%$ fractions are significantly higher than other fractions. To calculate the compressive strength in (MPa) uses the equation:

$$
\mathrm{F}_{\mathrm{c}}^{\prime}=\mathrm{P} / \mathrm{A}
$$

Where:

$\mathrm{F}^{\prime} \mathrm{c}=$ Compressive strength $(\mathrm{MPa})$

$\mathrm{P}=$ Total maximum load $(\mathrm{N})$

$\mathrm{A}=$ Section area of cubic

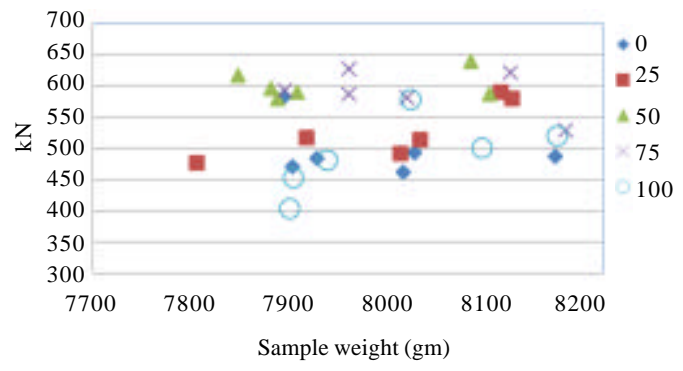

Fig. 4: Analyzed samples strength as a function of slurry used fraction compressive strength with slurry $\%$

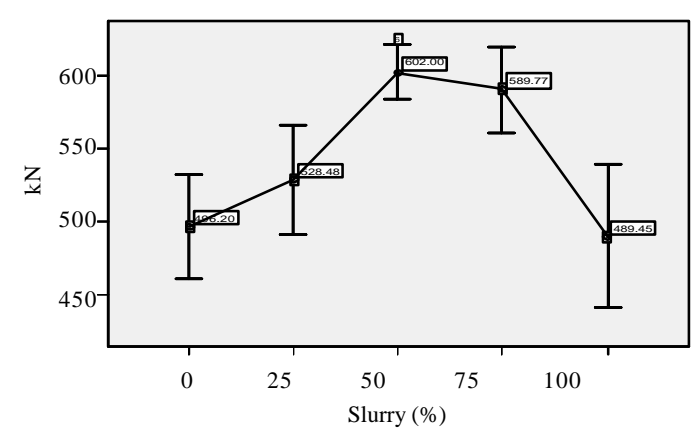

Fig. 5: Average and range of sample strength as a function of slurry fraction strength vs. slurry $\%$



Fig. 6: Compressive strength as a function of slurry fraction (standard compressive strength)

Maximum compressive strength of $26.7 \mathrm{MPa}$ is observed at $50 \%$ slurry water as shown in Fig. 6 However, $75 \%$ show close strength.

Tens ile strength for $75 \%$ show highest mean ( 76 $\mathrm{MPa}$ )with large variability and $50 \%$ has lowest value with $66 \mathrm{MPa}$ as shown in Fig. 7. 


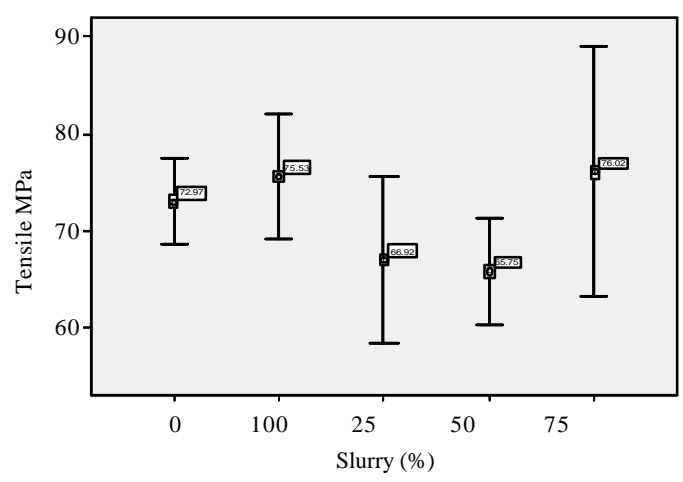

Fig. 7: Tensile strength as a function of slurry fraction

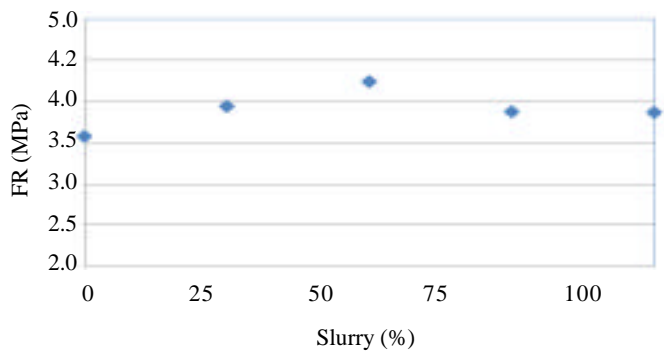

Fig. 8: Flexural strength as a function of slurry fraction

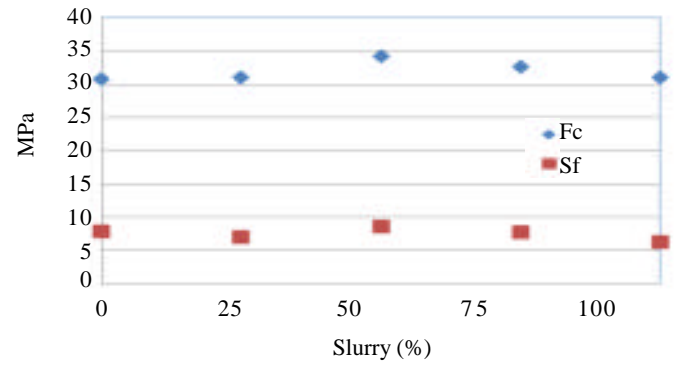

Fig. 9: Effect of slurry on mortar strength

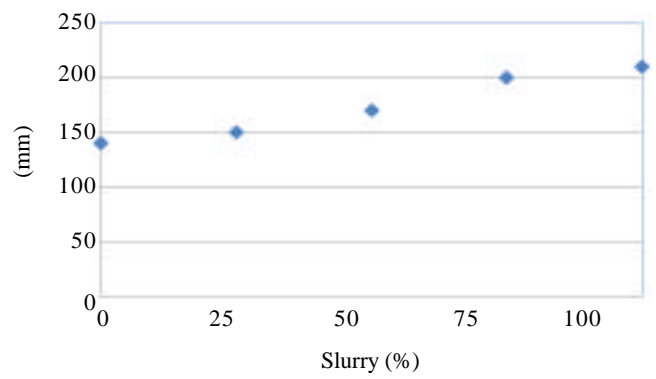

Fig. 10: Effect of slurry fraction on workability

Flexural strength for $50 \%$ show highest value of 4.2 MPaas shown in Fig. 8. To calculate the flexural strength in MPa use the equation:

$$
\mathrm{Sf}=0.0028 \mathrm{P}
$$

Where:

$$
\mathrm{Sf}=\text { Flexural strength in }(\mathrm{MPa})
$$$$
\mathrm{P}=\text { Total maximum } \operatorname{load}(\mathrm{N})
$$

Mortar compressive (fc) and flexural ( $\mathrm{Sf}$ ) strength are show in Fig. 9. The 50\% fraction show highest value for compressive and flexural strength with 34 and $8.6 \mathrm{MPa}$, respectively. Workability show increasing trend with increasing fraction of slurry as shown in Fig. 10.

\section{CONCLUSION}

This research shows that the stone cutting sludge can be utilized as a resource in concrete mix design and construction. Results indicate that using of slurry sludge as a fraction of tap water in concrete production has variable impact based on fraction. In this experiment, a $50 \%$ fraction of water amount shows maximum improvement in flexural and compressive strength. Also, adding slurry water consistently increased workability at all fractions. The results show consistency with similar literature in general, however, optimum fraction is different with comparison with Alzboon and Mahasneh (2009) at $25 \%$ from and Hamza et al., 2011 at 10\%. This variability is expected because type of stone and its physical properties are not unified across these studies. Therefore, we suggest conducting test on local slurry before making any recommendations.

The fine suspended material in the slurry could be successfully removed by physical settling. After settling, the produced water is suitable to use in concrete and it improves workability (slump) and compression strength. Stone cutting slurry properties vary with nature of parent rocks. Therefore, regional variation in rocks geology caus es variation in stone cutting slurry properties. So, optimal fraction of slurry used may differ based on the region. Concrete industry can utilize significant amounts of stone cutting waste in its operations which improves physical properties and reduces cost.

\section{NOMENCLATURE}

$\mathrm{f}^{\prime} \mathrm{cr} \quad=$ Specific strength in $(\mathrm{MPa})$

AASHTO $=$ American Association of State Highway and Transportation Officials

F'c $=$ Compressive strength $(\mathrm{MPa})$

$\mathrm{P}=$ Total maximum $\operatorname{load}(\mathrm{N})$

A $\quad=$ Section area of cubic

Sf $\quad=$ Flexural strength $(\mathrm{MPa})$

$\mathrm{P} \quad=$ total maximum load $(\mathrm{N}) \mathrm{sec}$ 


\section{REFERENCES}

A1-Joulani, N. and N. Salah, 2014. The stone slurry in palestine from environmental burden to economic opportunities-feasibility analysis. J. Environ. Prot., 5: 1075-1090.

Al-Rawashdeh, M. and A. Shaqadan, 2015. Effect of basalt aggregates and plasticizer on the compressive s trength of concrete. Intl. J. Eng. Technol., 4: 520-525.

AlZboon, K. and J. Al-Zou'by, 2015. Recycling of stone cutting slurry in concrete mixes. J. Mater. Cycles Waste Manage., 17: 324-335.

Almeida, N., F. Branco, J. de Brito and J.R. Santos, 2007. High-performance concrete with recycled stone slurry. Cement Concrete Res., 37: 210-220.

Alzboon, K.K. and K.N. Mahasneh, 2009. Effect of using stone cutting waste on the compression strength and slump characteristics of concrete. Int. J. Environ. Sci. Eng., 1: 167-172.

Binici, H., T. Shah, O. Aksogan and H. Kaplan, 2008. Durability of concrete made with granite and marble as recycle aggregates. J. Mater. Process. Technol., 208: 299-308.

Gambhir, M.L., 1986. Concrete Technology: Theory and Practice. 5th Edn., Tata Mcgraw Hill Education, New York, USA., ISBN: 9789332901063, Pages: 318 .

Grieb, W. and G. Werner, 1962. Comparison of the splitting tensile strength of concrete with flexural and compressive strengths. Publ. Roads, 32: 972-995.

Hamza, R.A., S. El-Haggar and S. Khedr, 2011. Marble and granite waste: Characterization and utilization in concrete bricks. Intl. J. Biosci. Biochem. Bioinf., 1: 286-286.

Kosmatka, S.H., K. Beatrix and C.P. William, 2002. Design and Control of Concrete Mixtures. 14th Edn., Portland Cement Association, Skokie, Illinois, ISBN:9780893122171, Pages: 358.
Neville, A.m. and J.J. Brooks, 2010. Concrete Technology. 2nd Edn., Prentice Hall, Harlow, England, ISBN:9780273732198, Pages: 442.

Persson, B., 1996. Hydration and strength of high performance concrete. Adv. Cem. Based Mater., 3: 107-123.

Popovics, S., 1998. Strength and Related Properties of Concrete a Quantitative Approach. John Wiley and Sons, Inc., New York, USA., ISBN: 0471149039, pp: 535.

Raphael, J.M., 1984. Tensile strength of concrete. J. Proc., 81: 158-165.

Safiuddin, M., S.N. Raman and M.F.M. Zain, 2007. Utilization of quarry waste fine aggregate in concrete mixtures. J. Appl. Sci. Res., 3: 202-208.

Senthamarai, R.M. and P.D. Manoharan, 2005. Concrete with ceramic waste aggregate. Cem. Concr. Compos., 27: 910-913.

Shaqadan, A., 2016. Prediction of concrete mix strength using random forest model. Intl. J. Appl. Eng. Res., 11: 11024-11029.

Shaqadan, A.A. and M. Al-Rawashdeh, 2018. Prediction of concrete mix compressive strength using statistical learning models. J. Eng. Sci. Technol., 13: 1916-1925.

Silva, J., J. de Brito and R. Veiga, 2009. Incorporation of fine ceramics in mortars. Constr. Build. Mater., 23: 556-564.

Tattersall, G.H., 1991. Workability and Quality Control of Concrete. Routledge, Abingdon, USA., ISBN: 9789990068269,.

Topcu, I.B. and M. Canbaz, 2007. Utilization of crushed tile as aggregate in concrete. Iran. J. Sci. Technol. Trans. Eng., 31: 561-565.

Tripathy, D.K. and S.V. Barai, 2006. Partial cement replacement using crusher stone dust. J. Inst. Eng. India Civ. Eng. Div., 87: 44-46. 